\title{
42. OCEANIC THOLEIITES FROM LEG 80 SITES (CELTIC SEA PASSIVE MARGIN, NORTHEASTERN ATLANTIC): GEOCHEMISTRY AND MINERALOGY ${ }^{1}$
}

\author{
R. C. Maury and H. Bellon, Université de Bretagne Occidentale \\ H. Bougault, Centre Océanologique de Bretagne \\ J. L. Joron, Laboratoire P. Süe, Centre National de la Recherche Scientifique \\ M. Bohn, Université de Bretagne Occidentale and Centre Océanologique de Bretagne \\ and \\ P. C. de Graciansky, École Nationale Supérieure des Mines²
}

\begin{abstract}
The Leg 80 basalts drilled on the Porcupine Abyssal Plain $10 \mathrm{~km}$ southwest of Goban Spur (Hole 550B) and on the western edge of Goban Spur (Hole 551), respectively, are typical light-rare-earth-element- (LREE-) depleted oceanic tholeiites. The basalts from the two holes are almost identical; most of their primary geochemical and mineralogical characteristics have been preserved, but they have undergone some low-temperature alteration by seawater, such as enrichment in $\mathrm{K}, \mathrm{Rb}$, and $\mathrm{Cs}$ and development of secondary potassic minerals of the "brownstone facies." $\mathrm{K} / \mathrm{Ar}$ dating fail to give realistic emplacement ages; the apparent ages obtained become younger with alteration (causing an increase in $\mathrm{K}_{2} \mathrm{O}$ ). Hole 551 basalts are clearly different from the continental tholeiites emplaced on the margins of oceanizing domains during the prerift and synrift stages.
\end{abstract}

\section{INTRODUCTION}

IPOD Leg 80 drilled a transect of four sites across the western European passive margin of the Atlantic Ocean Goban Spur, located $250 \mathrm{~km}$ southwest of Ireland. Basalts were recovered from the bottoms of two holes at the two most southwestern sites, Sites 550 and 551.

Hole 550B was drilled on the Porcupine Abyssal Plain (at $4432 \mathrm{~m}$ water depth), $10 \mathrm{~km}$ southwest of the seaward edge of Goban Spur, in a typically oceanic environment. A section of $35 \mathrm{~m}$ of basalt was recovered below the uppermost Albian calcareous mudstones. The upper part of the volcanic pile is made up of pillow lavas and hyaloclastites (Subunit 6a, $4 \mathrm{~m}$ thick), which are underlain by six lava flows (1-7 m thick). Three of them (Subunit $6 \mathrm{~b}$ ) are covered by thin layers of microfossilbearing limestones, the age of which does not seem very different from that of the Vraconian sediments overlying the volcanic sequence. The rate of emplacement of the lava flows was probably not very high.

Hole 551 was drilled on the western edge of Goban Spur (at $3909 \mathrm{~m}$ water depth) over the flat top of a raised basement block. This site was designed to determine the nature and age of basement constituting what was thought to be the oceanmost edge of the continental crust. Unexpectedly, however, the upper part of this basement proved to be made of $59 \mathrm{~m}$ of basaltic flows and pillows overlain by bathyal upper Cenomanian chalk.

\footnotetext{
${ }^{1}$ Graciansky, P. C, de, Poag, C. W., et al., Init. Repts. DSDP, 80: Washington (U.S. Govt, Printing Office).

2 Addresses: (Maury, Bellon, and Bohn) Université de Bretagne Occidentale, 29283 Brest, France; (Bougault and Bohn) COB-CNEXO, BP 337, 29273 Brest, France; (Joron) Laboratoire P. Süe, CNRS, CEN Saclay, BP 2, 91190 Gif-sur-Yvette, France; (de Graciansky) École Nationale Supérieure des Mines, 60, Boulevard Saint-Michel, 75272 Paris Cedex 06, France.
}

The volcanic sequence includes two units: an upper one (46 m thick) composed of pillow lavas and hyaloclastites and a lower one (23 m thick) composed of two thick lava flows.

Geochemical (major element and trace element $\mathrm{K} / \mathrm{Ar}$ isotopic dating) and mineralogical (microprobe) investigations have been conducted on 19 basalt samples (12 from Hole 550B and 7 from Hole 551), with two major goals:

1. Characterization of the oldest ocean crust in the area, and

2. Search for petrological or age differences between basalts from Sites 550 and 551 to try to solve the important question of the precise location of the ocean-continent boundary west of Goban Spur.

\section{LITHOLOGY}

Most of the samples are relatively fresh, with wellpreserved primary plagioclases and clinopyroxenes. All of them, however, have suffered some alteration, including complete destabilization of olivine (conversion to brown clays); development of brown clays (smectites and mixed-layer clays) and calcite in a previously glassy groundmass; oxidation of iron titanium oxides; and filling of void spaces by calcite and clays. These mineralogic transformations are typical of low-temperature alteration of basalts by seawater ("brownstone facies" of Cann, 1979).

The original textures are well preserved. Samples were obtained from every transitional textural type resulting from lava cooling, ranging from predominantly glassy textures (pillow rims) to microlitic and even subophitic textures (centers of lava flows). Most of the samples are porphyritic, with 1 to $2 \%$ olivine phenocrysts (altered) containing occasional chromite inclusions and 2 to $15 \%$ (commonly 5\%) plagioclase phenocrysts, sometimes of 
plurimillimetric size. Clinopyroxene phenocrysts occur sporadically. There is no systematic difference between Hole 550B and Hole 551 basalts with respect to the amount or nature of phenocrysts.

The groundmass is commonly made of acicular plagioclase and clinopyroxene, joined by tiny titanomagnetite octahedra in the well-crystallized samples. The original glasses have been converted to brown clays and calcite, which are also found filling vesicles and fractures. Secondary potassic feldspar (adularia type) occurs in the most altered samples, which commonly correspond to pillow or hyaloclastic fragments. This feldspar developed at the expense of the groundmass glass and has replaced plagioclase microlites and even phenocrysts. The basaltic sequence from Hole 551 is more altered than that from Hole $550 \mathrm{~B}$, and only a limited number of "fresh" samples are available for geochemical and microprobe studies. Chlorite and albite, common products of high-temperature hydrothermal alteration of oceanic basalts, are conspicuously lacking from the parageneses of Hole 550B and 551 basalts.

\section{MAJOR ELEMENT COMPOSITIONS}

The 19 analyses given in Table 1 are typical of oceanic tholeiites. The compositions are fairly constant, and most of them fall in the group of quartz tholeiites; only two samples can be classified as olivine tholeiites. The unique nepheline-normative composition (551-9-4, 47$52 \mathrm{~cm}$ ) corresponds to a deeply altered basalt (loss on ignition: $6.36 \%$ ). There is no systematic difference in major element compositions between Holes 550B and 551 . The most striking variations reflect the pattern of alteration: there is a strong positive correlation between the amount of $\mathrm{K}_{2} \mathrm{O}$ and the value of the loss on ignition
(LOI), with the fresh samples (LOI $<2 \%$ ) containing less than $0.1 \% \mathrm{~K}_{2} \mathrm{O}$. The altered basalts (LOI 2-6\%) are commonly enriched in $\mathrm{K}_{2} \mathrm{O}$ (up to $1 \%$ in Sample 551-9$4,47-52 \mathrm{~cm}$ ) and slightly enriched in $\mathrm{CaO}$, and somewhat depleted in $\mathrm{SiO}_{2}$ and $\mathrm{MgO}$. These chemical variations are typical of the low-temperature alteration sequence of oceanic basalt by seawater (Donnelly et al., 1979).

\section{MINERALOGY}

\section{Spinels}

Chromiferous spinels $\left(\mathrm{Cr}_{2} \mathrm{O}_{3}: 31-34 \%\right.$, Analyses 1, 2, and 3; Table 2) have been found as octahedra, as large as $50 \mu \mathrm{m}$ in size, included within altered olivine phenocrysts in Sample 551-8-1, 129-132 cm. They can be classified as magnesiochromites with $\mathrm{Mg} / \mathrm{Mg}+\mathrm{Fe}^{2+}=$ $0.66-0.73$ and $\mathrm{Cr} / \mathrm{Cr}+\mathrm{Al}=0.40-0.44$, but they appear to be intermediate between the magnesiochromite and chromian spinel groups defined by Sigurdsson and Schilling (1976) for Mid-Atlantic Ridge basalts. They are more $\mathrm{Al}$ rich than the common compositional range of spinels from oceanic basalts, and in fact, they have been found in the most $\mathrm{Al}$-rich basalt studied $\left(\mathrm{Al}_{2} \mathrm{O}_{3}\right.$ $17.9 \%$ ). This high alumina value seems to reflect alteration processes and/or possible accumulation of plagioclase phenocrysts. Indeed, using the relationship of Maurel and Maurel (1982) of $\left(\mathrm{Al}_{2} \mathrm{O}_{3}\right)_{\text {sp }}=0.035\left(\mathrm{Al}_{2} \mathrm{O}_{3}\right)_{\text {liq, }}$, the spinels studied would be in equilibrium with liquids containing 16.1 to $16.7 \% \mathrm{Al}_{2} \mathrm{O}_{3}$, which are reasonable values for oceanic tholeiites.

Titanomagnetite is a common mineral in the groundmass of microlitic or subophitic basalts of Leg 80 , but it is often found oxidized to maghemite. Some primary

Table 1. Basalts from Holes 550B and 551: major element analyses (wt.\%).

\begin{tabular}{|c|c|c|c|c|c|c|c|c|c|c|c|c|c|c|c|c|c|c|c|}
\hline \multirow[b]{2}{*}{$\begin{array}{c}\text { Sample } \\
\text { Interval (cm) }\end{array}$} & \multicolumn{12}{|c|}{ Hole 550B } & \multicolumn{7}{|c|}{ Hole 551} \\
\hline & $\begin{array}{c}26-1 \\
33-36\end{array}$ & $\begin{array}{c}26-3 \\
88-91\end{array}$ & $\begin{array}{c}27-1 \\
65-68\end{array}$ & $\begin{array}{c}27-3 \\
33-36\end{array}$ & $\begin{array}{c}28-1 \\
94-97\end{array}$ & $\begin{array}{c}28-2 \\
72-74\end{array}$ & $\begin{array}{c}28-5 \\
129-131\end{array}$ & $\begin{array}{l}29-1 \\
1-5\end{array}$ & $\begin{array}{l}29-3 \\
5-8\end{array}$ & $\begin{array}{c}29-4 \\
57-60\end{array}$ & $\begin{array}{c}30-1 \\
32-37\end{array}$ & $\begin{array}{l}30-5 \\
0-4\end{array}$ & $\begin{array}{c}8-1 \\
129-132\end{array}$ & $\begin{array}{c}9-4 \\
47-52\end{array}$ & $\begin{array}{c}10-3 \\
35-39\end{array}$ & $\begin{array}{c}11-5 \\
98-102\end{array}$ & $\begin{array}{c}12-3 \\
99-103\end{array}$ & $\begin{array}{c}13-5 \\
72-75\end{array}$ & $\begin{array}{c}14-1 \\
23-27\end{array}$ \\
\hline $\mathrm{SiO}_{2}$ & 48.47 & 49.30 & 47.86 & 48.05 & 47.45 & 48.24 & 50.06 & 47.74 & 49.20 & 47.95 & 48.38 & 48.89 & 48.94 & 42.99 & 48.23 & 50.03 & 49.36 & 48.50 & 48.64 \\
\hline $\mathrm{TiO}_{2}$ & 1.36 & 1.49 & 1.74 & 1.66 & 1.16 & 1.49 & 1.49 & 1.60 & 1.47 & 1.37 & 1.43 & 1.23 & 1.09 & 0.92 & 1.03 & 1.16 & 1.44 & 1.30 & 1.72 \\
\hline $\mathrm{Al}_{2} \mathrm{O}_{3}$ & 15.92 & 15.00 & 16.69 & 16.62 & 16.76 & 15.98 & 15.53 & 17.14 & 15.07 & 16.62 & 16.60 & 16.99 & 17.88 & 15.57 & 17.81 & 16.39 & 17.25 & 15.67 & 17.17 \\
\hline $\mathrm{Fe}_{2} \mathrm{O}_{3}{ }^{\mathrm{a}}$ & 10.25 & 12.51 & 12.32 & 11.22 & 9.24 & 11.41 & 11.47 & 11.67 & 12.55 & 10.96 & 10.89 & 10.69 & 8.15 & 9.45 & 8.51 & 7.75 & 8.61 & 10.62 & 11.17 \\
\hline $\mathrm{MnO}$ & 0.12 & 0.18 & 0.08 & 0.16 & 0.16 & 0.19 & 0.20 & 0.12 & 0.20 & 0.17 & 0.13 & 0.17 & 0.13 & 0.14 & 0.13 & 0.14 & 0.17 & 0.15 & 0.16 \\
\hline $\mathrm{MgO}$ & 6.19 & 6.51 & 7.22 & 6.70 & 6.24 & 6.70 & 6.20 & 6.89 & 7.16 & 7.21 & 6.45 & 6.44 & 6.42 & 5.96 & 6.78 & 8.12 & 7.62 & 8.43 & 6.48 \\
\hline $\mathrm{CaO}$ & 11.90 & 11.74 & 7.54 & 10.82 & 12.82 & 12.57 & 12.39 & 9.52 & 12.22 & 11.30 & 10.78 & 13.06 & 12.80 & 15.74 & 13.66 & 12.86 & 11.72 & 11.42 & 10.71 \\
\hline $\mathrm{Na}_{2} \mathrm{O}$ & 2.01 & 1.90 & 2.42 & 2.00 & 2.56 & 1.67 & 1.83 & 2.21 & 1.52 & 1.95 & 1.98 & 1.5 & 1.65 & 1.29 & 1.77 & 1.95 & 2.30 & 2.07 & 2.27 \\
\hline $\mathrm{K}_{2} \mathrm{O}$ & .33 & 0.04 & 0.07 & 0.02 & 0.02 & 0.01 & 0.01 & 0.14 & 0.02 & 0.02 & 0.37 & 0.0 & 0.88 & 1.01 & 0.05 & 0.10 & 0.08 & 0.07 & 0.03 \\
\hline $\mathrm{P}_{2} \mathrm{O}_{5}$ & 0.17 & 0.17 & 0.17 & 0.19 & 0.14 & 0.17 & 0.20 & 0.16 & 0.17 & 0.15 & 0.16 & 0.15 & 0.12 & 0.12 & 0.12 & 0.11 & 0.16 & 0.15 & 0.19 \\
\hline LoI $^{6}$ & 2.56 & 0.75 & 1.97 & 1.81 & 3.84 & 1.40 & 0.83 & 2.33 & 0.90 & 1.94 & 2.20 & 0.86 & 2.49 & 6.36 & 1.86 & 1.00 & 1.50 & 1.71 & 1.12 \\
\hline Total & 99.28 & 99.59 & 98.08 & 99.25 & 100.39 & 99.83 & 100.21 & 99.52 & 100.48 & 99.64 & 99.37 & 100.01 & 100.55 & 99.55 & 99.95 & 99.61 & 100.21 & 100.09 & 99.66 \\
\hline Q & 1.56 & 2.81 & 1.61 & 1.81 & & 1.8 & 4.09 & 0.55 & 3.02 & 0.5 & 1.5 & 2.67 & 0.4 & & 0.1 & 1. & 0.02 & & 1.22 \\
\hline Or & 2.03 & 0.24 & 0.43 & 0.12 & 0.12 & 0.0 & 0.06 & 0.86 & 0.12 & 0.12 & 2.27 & & 5.34 & 6.46 & 0.30 & 0.60 & 0.48 & 0.42 & 0.18 \\
\hline $\mathrm{Ab}$ & 17.73 & 16.43 & 21.52 & 17.53 & 22.60 & 14.49 & 15.72 & 19.42 & 13.05 & 17.04 & 17.39 & 13.17 & 14.33 & 2.41 & 15.37 & 16.83 & 19.85 & 17.96 & 19.66 \\
\hline $\begin{array}{c}\mathrm{An} \\
\mathrm{Ne}\end{array}$ & 34.88 & 33.01 & 36.25 & 37.62 & 35.68 & 37.01 & 34.67 & 37.86 & 34.74 & 37.75 & 36.68 & 40.19 & 38.82 & 36.48 & 41.59 & 36.41 & 37.25 & 34.11 & 37.46 \\
\hline${ }^{\mathrm{Ne}}$ Wo & 10.70 & 10.65 & 34 & 7.02 & 12.46 & 10. & 11.09 & 4.27 & 10 & & & & [0 & $\begin{array}{r}5.09 \\
19.72\end{array}$ & & & & & 6.60 \\
\hline Di En & 98 & & 0.4 & 3 & & & & 2. & & 4. & 4. & 5. & 6.25 & 10.95 & 6.90 & 7.71 & 5.60 & 5.84 & 3.67 \\
\hline Fs & 4.30 & 4.77 & 0.34 & 2.81 & 4.72 & 4.47 & 4.82 & 1.73 & 4.57 & 3.09 & 3.05 & 4.27 & 3.47 & 8.00 & 3.86 & 3.16 & 2.65 & 3.27 & 2.67 \\
\hline En & 10.10 & 11.00 & 18.43 & 13.35 & 3.49 & 11.15 & 9.77 & 15.45 & 12.28 & 13.95 & 12.55 & 10.60 & 10.16 & & 10.43 & 12.92 & 13.76 & 13.47 & 12.86 \\
\hline Fs & 7.27 & 9.43 & 13.38 & 9.54 & 2.29 & 8.37 & 7.97 & 11.29 & 9.65 & 9.39 & 9.24 & 7.92 & 5.64 & & 5.83 & 5.29 & 6.51 & 7.53 & 9.38 \\
\hline Fo & & & & & 3.89 & & & & & & & & & 3.58 & & & & 1.55 & \\
\hline $\mathrm{Fa}$ & & & & & 2.82 & & & & & & & & & 2.88 & & & & 0.96 & \\
\hline $\mathrm{Mt}$ & 2.33 & 2.79 & 2.82 & 2.52 & 2.10 & 2. & 2. & 2.64 & 2. & 2 & 2.4 & 2. & 1.82 & 2.23 & 1. & 1.72 & 1.91 & 2.36 & 2.49 \\
\hline II & 2.69 & 2.89 & 3.48 & 3.27 & 2.30 & 2.90 & 2.87 & 3.16 & 2.83 & 2.69 & 2.82 & 2. & 2.13 & 1.89 & 2.01 & 2.25 & 2.79 & 2.53 & 3.35 \\
\hline A & 0.42 & 0.41 & 0.42 & & & 0. & 0. & 0.39 & 0. & 0.3 & 0.3 & 0.36 & 0.29 & 0.31 & 0.29 & 0.27 & 0.39 & 0.36 & 0.46 \\
\hline D.I.c & 21.32 & 19.48 & 23.56 & 19.46 & 22.72 & 16.37 & 19.87 & 20.83 & 16.18 & 17.67 & 21.22 & 15.84 & 20.13 & 13.96 & 15.81 & 18.57 & 20.34 & 18.38 & 21.07 \\
\hline S.I..$^{d}$ & 34.63 & 32.73 & 34.59 & 35.32 & 36.07 & 35.56 & 33.41 & 34.68 & 35.46 & 37.54 & 34.44 & 36.26 & 39.13 & 35.25 & 41.36 & 46.98 & 42.52 & 41.59 & 34.10 \\
\hline
\end{tabular}

a Total iron as $\mathrm{Fe}_{2} \mathrm{O}_{3}$. The CIPW norms are calculated with $85 \%$ of total iron as $\mathrm{FeO}$ and $15 \%$ as $\mathrm{Fe}_{2} \mathrm{O}_{3}$.

b $\mathrm{LOI}=1050^{\circ} \mathrm{C}$

D.I. $=$ Differentiation index.

S.I. = Solidification index. 
Table 2. Spinel analyses.

\begin{tabular}{|c|c|c|c|c|c|}
\hline \multirow{2}{*}{$\begin{array}{c}\text { Sample } \\
\text { Analyses }^{\mathrm{a}}\end{array}$} & \multicolumn{3}{|c|}{$\begin{array}{c}551-8-1 \\
(129-132 \mathrm{~cm})\end{array}$} & \multicolumn{2}{|c|}{$\begin{array}{l}550 \mathrm{~B}-26-3 \\
(88-91 \mathrm{~cm})\end{array}$} \\
\hline & 1 & 2 & 3 & 4 & 5 \\
\hline $\mathrm{SiO}_{2}$ & 0.11 & 0.09 & 0.07 & 0.12 & 0.18 \\
\hline $\mathrm{TiO}_{2}$ & 0.44 & 0.32 & 0.55 & 20.57 & 21.54 \\
\hline $\mathrm{Al}_{2} \mathrm{O}_{3}$ & 31.93 & 30.91 & 28.71 & 2.43 & 1.86 \\
\hline $\mathrm{Cr}_{2} \mathrm{O}_{3}$ & 31.42 & 32.38 & 33.76 & 0.00 & 0.00 \\
\hline $\mathrm{Fe}_{2} \mathrm{O}_{3}$ & 7.47 & 7.67 & 8.43 & 25.96 & 24.01 \\
\hline $\mathrm{FeO}$ & 12.60 & 11.18 & 13.95 & 49.05 & 49.98 \\
\hline $\mathrm{MnO}$ & 0.22 & 0.17 & 0.27 & 0.75 & 0.63 \\
\hline $\mathrm{MgO}$ & 16.09 & 16.70 & 15.01 & 0.32 & 0.13 \\
\hline $\mathrm{CaO}$ & 0.00 & 0.02 & 0.08 & 0.09 & 0.18 \\
\hline Total & 100.28 & 99.44 & 100.83 & 99.29 & 98.51 \\
\hline $\mathrm{Si}$ & 0.026 & 0.022 & 0.016 & 0.037 & 0.055 \\
\hline $\mathrm{Ti}$ & 0.077 & 0.057 & 0.098 & 4.623 & 4.395 \\
\hline $\mathrm{Al}$ & 8.741 & 8.520 & 7.978 & 0.855 & 0.664 \\
\hline & 5.769 & 5.988 & 6.294 & 0.000 & 0.000 \\
\hline $\mathrm{Fe}^{3+}$ & 1.305 & 1.349 & 1.496 & 5.838 & 5.460 \\
\hline $\mathrm{Fe}^{2+}$ & 2.448 & 2.188 & 2.751 & 12.262 & 12.635 \\
\hline $\mathrm{Mn}$ & 0.043 & 0.035 & 0.055 & 0.189 & 0.162 \\
\hline $\mathrm{Mg}$ & 5.570 & 5.821 & 5.276 & 0.141 & 0.056 \\
\hline $\mathrm{Ca}$ & 0.000 & 0.005 & 0.019 & 0.029 & 0.059 \\
\hline
\end{tabular}

Note: All the microprobe analyses presented in this paper (Tables 2, 3, and 4) have been obtained with a Camebaxtype automated microprobe (Microsonde Ouest, Brest; working conditions $15 \mathrm{kV}, 10 \mathrm{nA}$; counting time, $6 \mathrm{sec}$. concentrations lower than $0.3 \%$ are not considered representative).

a Analyses 1, 2, and 3: inclusions in olivine phenocrysts; 4 and 5: titanomagnetite octahedra from the groundmass. $\mathrm{Fe}^{3+}$ has been estimated by stoichiometry to 24 cations and 32 oxygens. compositions $\left(\mathrm{TiO}_{2} 20.5-21.5 \%\right)$ are given in Table 2 (Analyses 4 and 5).

\section{Clinopyroxenes}

Clinopyroxene phenocrysts, as large as $500 \mu \mathrm{m}$ in diameter, occur sporadically. They are iron poor ( $\mathrm{FeO} 5-$ $7 \%$; Table 3) and plot near the endiopside-augite boundary in the $\mathrm{Ca}-\mathrm{Mg}-(\mathrm{Fe}+\mathrm{Mn})$ diagram (Fig. 1). They differ consistently from the groundmass clinopyroxenes by their lower $\mathrm{TiO}_{2}$ and higher $\mathrm{MgO}$ and $\mathrm{Cr}_{2} \mathrm{O}_{3}$ (up to $1.2 \%$ ) contents. Their compositions are typical of clinopyroxene phenocrysts from oceanic tholeiites (Leterrier et al., 1982) and are very similar in Holes 550B and 551.

The compositions of the extreme rims of clinopyroxene phenocrysts and those of groundmass clinopyroxenes show a considerable scatter in the $\mathrm{Ca}-\mathrm{Mg}-(\mathrm{Fe}+$ $\mathrm{Mn}$ ) diagram of Figure 1, where they plot mostly in the augite and ferroaugite fields. They follow a rough trend of iron enrichment typical of a tholeiitic series, with the most iron-rich compositions ( $45 \%$ ferrosilite) corresponding to the smaller crystals in well-crystallized (subophitic) samples. In fact, the compositional scatter of clinopyroxenes from any given individual sample is much less than for all samples combined. Figure 1B shows two extreme cases of variations, corresponding, respectively, to pyroxenes from a quickly cooled basalt $(550 \mathrm{~B}-28-5$, $129-131 \mathrm{~cm})$ and from a subophitic one (551-13-5, 72$75 \mathrm{~cm}$ ). The pyroxenes from the first sample show a typical quench trend (Smith and Lindsley, 1971), and those from the second one exhibit a regular and pronounced iron enrichment.

Table 3. Clinopyroxene analyses.

\begin{tabular}{|c|c|c|c|c|c|c|c|c|c|c|c|c|c|c|c|}
\hline \multirow{2}{*}{$\begin{array}{l}\text { Sample } \\
\text { Analysis }\end{array}$} & \multicolumn{3}{|c|}{$\begin{array}{l}550 \mathrm{~B}-26-3 \\
(88-91 \mathrm{~cm})\end{array}$} & \multicolumn{3}{|c|}{$\begin{array}{c}550 \mathrm{~B}-28-5 \\
(129-131 \mathrm{~cm})\end{array}$} & \multicolumn{5}{|c|}{$\begin{array}{l}550 \mathrm{~B}-29-3 \\
(5-8 \mathrm{~cm})\end{array}$} & \multicolumn{4}{|c|}{$\begin{array}{c}551-8-1 \\
(129-132 \mathrm{~cm})\end{array}$} \\
\hline & 6 & 7 & 8 & 9 & 10 & 11 & 12 & 13 & 14 & 15 & 16 & 17 & 18 & 8 & 19 \\
\hline $\mathrm{SiO}_{2}$ & 47.59 & 48.88 & 49.13 & 48.95 & 49.57 & 49.83 & 50.38 & 50.32 & 49.12 & 48.27 & 48.38 & 47.7 & & 8.94 & 49.50 \\
\hline $\mathrm{TiO}_{2}$ & 2.01 & 1.30 & 1.12 & 1.35 & 1.37 & 1.00 & 0.56 & 0.70 & 1.23 & 1.25 & $1.3 \mathrm{C}$ & 1.9 & & 1.33 & 1.36 \\
\hline $\mathrm{Al}_{2} \mathrm{O}_{3}$ & 5.38 & 2.42 & 2.45 & 4.38 & 3.38 & 2.42 & 3.85 & 4.26 & 4.33 & 2.82 & 2.6 & 5.9 & & 3.95 & 2.45 \\
\hline $\mathrm{Cr}_{2} \mathrm{O}_{3}$ & 0.19 & 0.00 & 0.00 & 0.20 & 0.04 & 0.01 & 0.59 & 0.47 & 0.20 & 0.0 & 0.00 & 0.2 & & 0.11 & 0.00 \\
\hline Feó & 11.98 & 18.29 & 23.19 & 10.60 & 12.99 & 17.43 & 6.83 & 6.86 & 10.96 & 16.96 & 20.2 & 10.6 & & 2.85 & 19.02 \\
\hline $\mathrm{MnO}$ & 0.12 & 0.48 & 0.53 & 0.35 & 0.28 & 0.38 & 0.29 & 0.22 & 0.26 & 0.42 & 0.6 & 0.1 & & 0.40 & 0.60 \\
\hline $\mathrm{MgO}$ & 12.10 & 14.12 & 8.02 & 14.22 & 14.91 & 15.02 & 19.18 & 18.08 & 14.91 & $1 \quad 12.99$ & 99 & 11.5 & & 3.15 & 9.83 \\
\hline $\mathrm{CaO}$ & 20.71 & 13.54 & 15.63 & 19.66 & 17.15 & 14.41 & 17.68 & 18.45 & 18.69 & 15.98 & 14.8 & 21.5 & & 8.96 & 17.64 \\
\hline $\mathrm{Na}_{2} \mathrm{O}$ & 0.27 & 0.27 & 0.36 & 0.27 & 0.30 & 0.22 & 0.21 & 0.25 & 0.33 & 0.25 & 0.1 & 0.3 & & 0.37 & 0.33 \\
\hline $\mathrm{K}_{2} \mathrm{O}$ & 0.00 & 0.00 & 0.03 & 0.00 & 0.00 & 0.00 & 0.00 & 0.00 & 0.00 & 0.00 & 0.0 & 0.0 & & 0.00 & 0.00 \\
\hline Total & 100.35 & 99.30 & 100.46 & 99.98 & 99.99 & 100.72 & 99.57 & 99.61 & 100.03 & $\begin{array}{ll}3 & 99.02\end{array}$ & 99.5 & is 100.1 & & 0.06 & 100.73 \\
\hline $\mathrm{Ca}$ & 44.1 & 28.3 & 34.5 & 41.0 & 35.5 & 29.3 & 35,4 & 37.6 & 38.8 & 33.5 & 31 & 46.7 & & 9.9 & 37.8 \\
\hline & 35.8 & 41.1 & 24.6 & 41.2 & 43.0 & 42.4 & 53.4 & 51.2 & 43.0 & 32.0 & 33. & 35.0 & & 8.4 & 29.3 \\
\hline $\mathrm{Fe}+\mathrm{Mn}$ & 20.1 & 30.6 & 40.9 & 17.8 & 21.5 & 28.3 & 11.2 & 11.2 & 18.2 & 28.5 & 34.7 & 18.3 & & 1.7 & 32.9 \\
\hline \multirow{2}{*}{$\begin{array}{l}\text { Sample } \\
\text { Analysis }\end{array}$} & \multicolumn{5}{|c|}{$\begin{array}{c}551-11-5 \\
(98-102 \mathrm{~cm})\end{array}$} & \multicolumn{6}{|c|}{$\begin{array}{c}551-13-5 \\
(72-75 \mathrm{~cm})\end{array}$} & \multicolumn{4}{|c|}{$\begin{array}{c}551-14-1 \\
(23-27 \mathrm{~cm})\end{array}$} \\
\hline & 20 & 21 & 22 & 23 & 24 & 25 & 26 & 27 & 28 & 29 & 30 & 31 & 32 & 33 & \\
\hline $\mathrm{SiO}_{2}$ & 50.92 & 50.64 & 50.81 & 48.90 & 48.61 & 50.81 & 49.85 & 50.22 & 49,81 & 50.40 & 48.75 & 49.20 & 48.42 & 47.42 & \\
\hline $\mathrm{TiO}_{2}$ & 0.50 & 0.71 & 0.73 & 1.26 & 0.77 & 0.68 & 0.88 & 0.79 & 0.94 & 0.84 & 0.86 & 1.15 & 1.24 & 1.62 & \\
\hline $\mathrm{Al}_{2} \mathrm{O}_{3}$ & 3.91 & 3.67 & 3.42 & 2.27 & 1.47 & 3.88 & 4.79 & 4.18 & 4.11 & 3.81 & 1.46 & 4.75 & 4.79 & 6.70 & \\
\hline $\mathrm{Cr}_{2} \mathrm{O}_{3}$ & 0.24 & 0.10 & 0.12 & 0.09 & 0.00 & 0.69 & 1.17 & 0.45 & 0.52 & 0.07 & 0.01 & 0.01 & 0.09 & 0.13 & \\
\hline $\mathrm{FeO}$ & 6.38 & 6.90 & 7.21 & 17.87 & 23.88 & 5.38 & 5.43 & 6.41 & 6.76 & 7.72 & 23.76 & 11,80 & 11.19 & 9.45 & \\
\hline $\mathrm{MnO}$ & 0.09 & 0.06 & 0.18 & 0.49 & 0.58 & 0.17 & 0.13 & 0.14 & 0.18 & 0.16 & 0.74 & 0.19 & 0.24 & 0.26 & \\
\hline $\mathrm{MgO}$ & 16.36 & 16.18 & 16.08 & 10.94 & 7.15 & 16.54 & 15.79 & 16.17 & 16.14 & 15.40 & 6.64 & 13.13 & 12.26 & 12.70 & \\
\hline $\mathrm{CaO}$ & 20.88 & 20.89 & 20.76 & 17.55 & 17.44 & 21.03 & 21.07 & 20.76 & 20.33 & 20.47 & 16.77 & 19.80 & 21.04 & 20.38 & \\
\hline $\mathrm{Na}_{2} \mathrm{O}$ & 0.26 & 0.25 & 0.23 & 0.34 & 0.17 & 0.25 & 0.25 & 0.26 & 0.31 & 0.31 & 0.32 & 0.33 & 0.35 & 0.38 & \\
\hline $\mathrm{K}_{2} \mathrm{O}$ & 0.00 & 0.00 & 0.00 & 0.01 & 0.03 & 0.00 & 0.00 & 0.00 & 0.00 & 0.00 & 0.01 & 0.00 & 0.02 & 0.00 & \\
\hline Total & 99.54 & 99.40 & 99.54 & 99.72 & 100.10 & 99.43 & 99.36 & 99.38 & 99.10 & 99.18 & 99.32 & 100.36 & 99.64 & 99.04 & \\
\hline $\mathrm{Ca}$ & 42.9 & 42.8 & 42.5 & 37.3 & 37.5 & 43.4 & 44.5 & 42.9 & 42.2 & 42.6 & 37.1 & 41.8 & 44.7 & 44.7 & \\
\hline $\mathrm{Mg}$ & & 46.1 & & & & 47.6 & 46.4 & 46.5 & & & & & 36.3 & 38.7 & \\
\hline $\mathrm{Fe}+\mathrm{Mn}$ & 10.4 & 11.1 & 11.8 & 30.4 & 41.1 & 9.0 & 9.1 & 10.6 & 11.2 & 12.8 & 42.4 & 19.7 & 19.0 & 16.6 & \\
\hline
\end{tabular}

Note: Cores of phenocrysts include analyses $12,13,20,21,25,26,27,28$, and 29; all other analyses are of groundmass pyroxenes. Total iron expressed as FeO. 


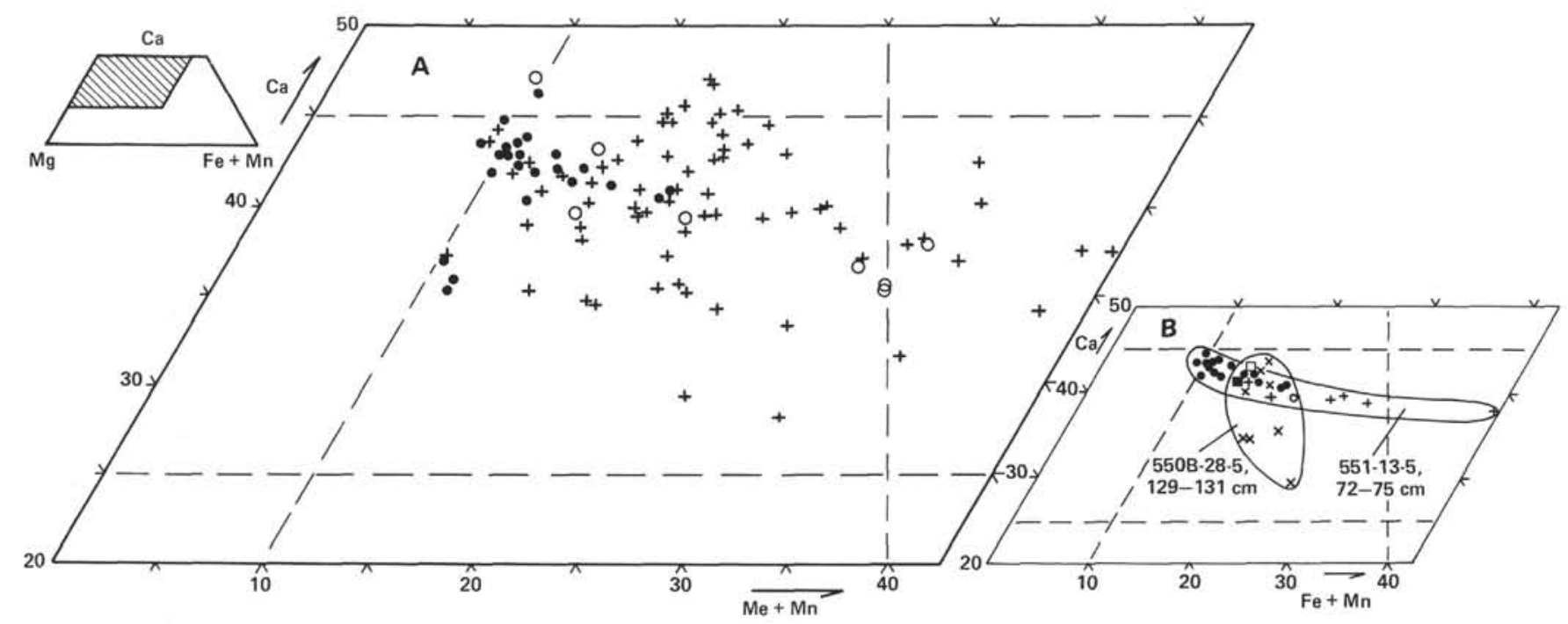

Figure 1. Clinopyroxene compositions plotted on the $\mathrm{Ca}-\mathrm{Mg}-(\mathrm{Fe}+\mathrm{Mn})$ diagram. A. Plot of all the compositions obtained. $-\mathbf{=}$ cores of phenocrysts; $O=$ rims of phenocrysts; $+=$ groundmass pyroxenes. B. Plot of the compositions of pyroxenes from two samples, 551-13-5, 72-75 cm (symbols as in A) and 550B-28-5 (129-131 cm); $=$ cores of phenocrysts; $\square=$ rims of phenocrysts; $\times=$ groundmass crystals.

\section{Plagioclases}

The compositions of the cores of the phenocrysts vary from $\mathrm{An}_{90}$ to $\mathrm{An}_{70}$, but individual crystals are rarely zoned (with the exception of the extreme rims, the composition of which is quite similar to that of microlites). In most cases compositional variations in a single phenocryst do not exceed 2 to $3 \%$ of anorthite component, which is quite uncommon in oceanic tholeiites. For instance, 10 microprobe analyses made from the core to the rim of a crystal $2.5 \mathrm{~mm}$ in diameter in Sample 550B-26-3, 88-91 cm, show a very restricted range of compositions: $\mathrm{An}_{86.7}$ to $\mathrm{An}_{85.7}$ (mean $\mathrm{An}_{86.1}$, standard deviation 0.35 ). The compositional ranges of plagioclase phenocrysts from Holes 550B and 551 are similar. Figure 2 shows a rough correlation between the anorthite content and the size of plagioclase phenocrysts, the larger ones being the most An rich and thus presumably representative of early crystallized minerals (Natland, 1978). These long (plurimillimetric) crystals usually contain glassy inclusions (Analyses 41, 42, and 43; Table 4). The compositions of these inclusions, however, cannot be considered representative of early liquids, because they have experienced crystallization of a basic plagioclase rim at the contact with their host mineral. Their analyses are thus considerably depleted in $\mathrm{Al}$ and enriched in $\mathrm{Mg}$ and $\mathrm{Fe}$.

The compositions of the groundmass plagioclases and those of extreme rims of phenocrysts show considerable variations from $\mathrm{An}_{75}$ to $\mathrm{An}_{33}$, the most common ones being $\mathrm{An}_{60-70}$. As previously discussed for groundmass pyroxenes, these variations are primarily linked to the cooling rates, the most sodic plagioclases being found in well-crystallized samples with subophitic textures.

Lastly, all the primary plagioclases analyzed contain no or extremely low amounts of potassium, any concen-

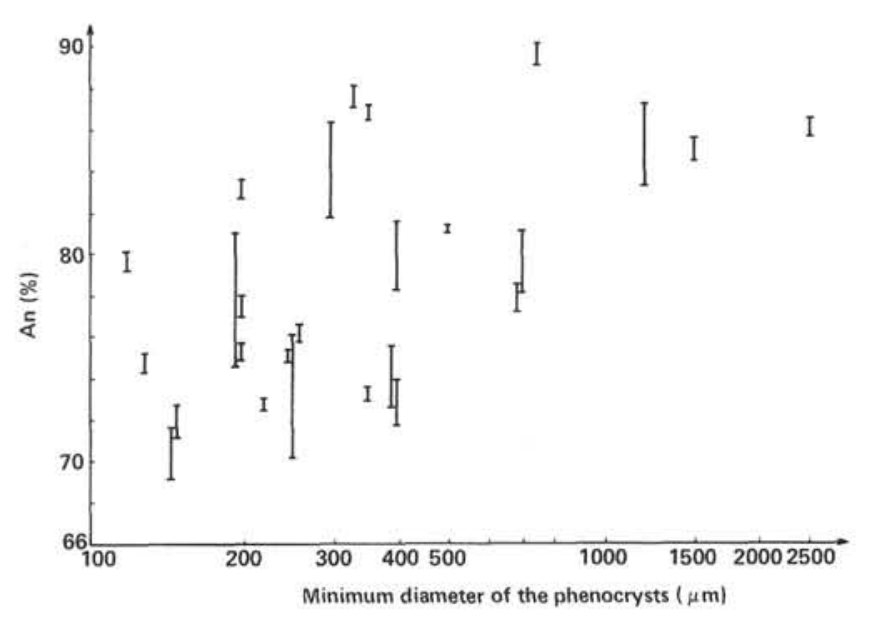

Figure 2. Anorthite content of plagioclase phenocrysts of various sizes. The extreme rims of the phenocrysts, the compositions of which are generally similar to those of groundmass crystals, have not been taken into consideration in this diagram.

tration of $\mathrm{K}_{2} \mathrm{O}$ being significant under the microprobe analytical conditions used (see Table 2 note).

\section{Secondary Minerals}

Although secondary minerals have not been studied in detail, a microprobe investigation was carried out on samples used for $\mathrm{K} / \mathrm{Ar}$ analysis to find where within the samples potassium is concentrated. It appears that in "fresh" basalt $\left(\mathrm{K}_{2} \mathrm{O}<0.1 \%\right)$, potassium is concentrated in K-poor clays $\left(\mathrm{K}_{2} \mathrm{O}<0.5 \%\right.$, Analyses 48,49 , and 50; Table 4) developed at the expense of primary glasses. In altered basalts $\left(\mathrm{K}_{2} \mathrm{O}>0.1 \%\right)$, these minerals are also present but are joined by $\mathrm{K}$-rich clays $\left(\mathrm{K}_{2} \mathrm{O} 2.5-\right.$ $10 \%$, Analyses 51, 52, and 53; Table 4) and by adulariatype secondary potassic feldspars $\left(\mathrm{K}_{2} \mathrm{O} \sim 17 \%\right.$, Analyses 44-47; Table 4). 
Table 4. Feldspars, glasses, and secondary mineral analyses from samples studied by the $\mathrm{K}-\mathrm{Ar}$ method.

\begin{tabular}{|c|c|c|c|c|c|c|c|c|c|c|c|}
\hline \multirow{2}{*}{$\begin{array}{c}\text { Phase } \\
\text { Analyses }\end{array}$} & \multicolumn{7}{|c|}{ Primary plagioclases } & \multicolumn{4}{|c|}{ Glassy inclusions } \\
\hline & 34 & 35 & 36 & 37 & 38 & 39 & 40 & 4 & & 42 & 43 \\
\hline $\mathrm{SiO}_{2}$ & 46.60 & 49.47 & 54.45 & 45.99 & 52.25 & 49.10 & 60.18 & & 3.46 & 48.12 & 47.71 \\
\hline $\mathrm{TiO}_{2}^{2}$ & 0.00 & 0.05 & 0.11 & 0.04 & 0.00 & 0.03 & 0.0 & & 2.13 & 2.19 & 2.45 \\
\hline $\mathrm{Al}_{2} \mathrm{O}_{3}$ & 34.05 & 31.48 & 27.34 & 34.22 & 29.62 & 31.72 & 24.42 & & .31 & 4.93 & 5.80 \\
\hline $\mathrm{Cr}_{3} \mathrm{O}_{3}$ & 0.00 & 0.00 & 0.00 & 0.00 & 0.00 & 0.00 & 0.08 & & .09 & 0.04 & 0.02 \\
\hline $\mathrm{Fe}_{2} \mathrm{O}_{3}$ & 0.36 & 0.54 & 1.31 & 0.59 & 0.94 & 0.44 & 0.93 & & .03 & 19.52 & 19.53 \\
\hline Mno & 0.00 & 0.00 & 0.03 & 0.00 & 0.02 & 0.00 & 0.0 & & .22 & 0.28 & 0.27 \\
\hline $\mathrm{MgO}$ & 0.16 & 0.19 & 0.06 & 0.22 & 0.31 & 0.19 & 0.0 & & .15 & 13.65 & 13.76 \\
\hline $\mathrm{CaO}$ & 17.30 & 15.09 & 10.95 & 17.35 & 13.82 & 15.45 & 6.8 & & .28 & 11.11 & 10.94 \\
\hline $\mathrm{Na}_{2} \mathrm{O}$ & 1.54 & 2.76 & 5.10 & 1.43 & 3.72 & 2.53 & 7.5 & & 0.82 & 1.08 & 1.08 \\
\hline $\mathrm{K}_{2} \mathrm{O}$ & 0.00 & 0.00 & 0.04 & 0.00 & 0.01 & 0.00 & 0.1 & & .07 & 0.20 & 0.07 \\
\hline Total & 100.01 & 99.58 & 99.39 & 99.84 & 100.69 & 99.46 & $5 \quad 100.2$ & $25 \quad 101$ & .561 & 101.12 & 101.63 \\
\hline $\mathrm{K}$ & 0.0 & 0.0 & 0.3 & 0.0 & 0.1 & 0.0 & 0.6 & & & & \\
\hline $\mathrm{Na}$ & 13.9 & 24.9 & 45.6 & 13.0 & 32.7 & 22.9 & 66.3 & & & & \\
\hline $\mathrm{Ca}$ & 86.1 & 75.1 & 54.1 & 87.0 & 67.2 & 77.1 & 33.1 & & & & \\
\hline \multirow{2}{*}{$\begin{array}{l}\text { Phase } \\
\text { Analyses }\end{array}$} & \multicolumn{4}{|c|}{ Orthoclase (adularia-type) } & \multicolumn{3}{|c|}{ K-poor clays } & \multicolumn{3}{|c|}{$\mathrm{K}$-rich clays } & \\
\hline & 44 & 45 & 46 & 47 & 48 & 49 & 50 & 51 & 52 & 53 & \\
\hline $\mathrm{SiO}_{2}$ & 62.97 & 62.64 & 63.36 & 63.02 & 49.88 & 48.35 & 44.06 & 45.55 & 47.61 & $1 \quad 54.20$ & \\
\hline $\mathrm{TiO}_{2}$ & 0.00 & 0.00 & 0.01 & 0.00 & 0.00 & 0.03 & 0.05 & 0.07 & 0.07 & 0.01 & \\
\hline $\mathrm{Al}_{2} \mathrm{O}_{3}$ & 19.20 & 19.60 & 18.67 & 18.38 & 0.70 & 3.44 & 5.55 & 7.88 & 14.45 & $5 \quad 14.53$ & \\
\hline $\mathrm{Cr}_{2} \mathrm{O}_{3}$ & 0.00 & 0.01 & 0.00 & 0.16 & 0.02 & 0.00 & 0.00 & 0.02 & 0.00 & 0.00 & \\
\hline $\mathrm{Fe}_{2} \mathrm{O}_{3}$ & 0.00 & 0.00 & 0.04 & 0.04 & & & & & & & \\
\hline Te & & & & & 21.65 & 16.43 & 13.98 & 11.19 & 4.84 & 2.54 & \\
\hline $\mathrm{MnO}$ & 0.00 & 0.00 & 0.01 & 0.00 & 0.22 & 0.00 & 0.13 & 0.00 & 0.06 & 0.00 & \\
\hline $\mathrm{MgO}$ & 0.00 & 0.00 & 0.00 & 0.00 & 14.24 & 17.60 & 15.70 & 13.65 & 14.24 & 9.35 & \\
\hline $\mathrm{CaO}$ & 0.00 & 0.02 & 0.04 & 0.02 & 0.79 & 1.09 & 0.81 & 1.13 & 0.79 & 0.46 & \\
\hline $\mathrm{Na}_{2} \mathrm{O}$ & 0.53 & 0.63 & 0.34 & 0.33 & 0.12 & 0.30 & 0.39 & 0.48 & 0.38 & 0.58 & \\
\hline $\mathrm{K}_{2} \mathrm{O}$ & 17.24 & 16.99 & 17.35 & 17.39 & 0.39 & 0.50 & 0.26 & 2.55 & 3.00 & 10.64 & \\
\hline Total & 99.94 & 99.89 & 99.82 & 99.34 & 88.01 & 88.74 & 80.93 & 82.52 & 85.44 & $4 \quad 92,31$ & \\
\hline K & 95.5 & 94.6 & 96.9 & 97.1 & & & & & & & \\
\hline $\mathrm{Na}$ & 4.5 & 5.3 & 2.9 & 2.8 & & & & & & & \\
\hline $\mathrm{Ca}$ & 0.0 & 0.1 & 0.2 & 0.1 & & & & & & & \\
\hline $\mathrm{Fm}$ & & & & & 6.3 & 34.4 & 1.5 & 1.5 & 16.2 & 13.2 & \\
\hline
\end{tabular}

Note: Analyses 34, 35, 36, 48, and 49 are from Sample 550B-26-3, 88-91 cm; 37, 38, 44, 45, 51, and 52 from Sample $551-8-1,129-132 \mathrm{~cm} ; 39,40,46,47,50$, and 53 from Sample $551-11-5,98-102$ $\mathrm{cm}$. Total iron is expressed as $\mathrm{Fe}_{2} \mathrm{O}_{3}$ for feldspars and glasses, as FeO for clay minerals. Analyses (4), 35, 37 in 39 are from cores of phenocrysts $2.5,0.2,1.2$, and 0.2 mm wide, respectively; 40 is from the
clases.
To summarize, in basalts from Leg 80 , potassium is almost exclusively found in secondary minerals; it is thus difficult to determine the age of emplacement of these basalts from $\mathrm{K} / \mathrm{Ar}$ data (as is true for other oceanic basalts).

\section{TRACE ELEMENT COMPOSITIONS}

The trace element compositions of basalts sampled in Hole 550B and 551 are given in Table 5; the elements are presented in order of increasing atomic number, including $\mathrm{Ti}, \mathrm{Mn}$, and $\mathrm{Fe}$. All measurements were made either by X-ray fluorescence spectrometry (XRF) at the Centre Océanologique de Bretagne (C.O.B.) (Bougault et al., 1977; Bougault, 1980) or by instrumental neutron activation (NAA) at the Laboratoire P. Süe (Treuil et al., 1973).

In general, Table 5 shows that the concentrations of trace elements in Leg 80 samples are typical of oceanic tholeiites and that there are no decisive differences between Hole 550B and 551 basalts. Nevertheless, some variations in these samples are observable. Some comments are necessary to point out the distinction between primary variations, possibly linked to partial melting or fractional crystallization, and those reflecting alteration. We will consider (1) alkali elements, (2) elements with high mineral/liquid partition coefficients (Ni and $\mathrm{Cr}$ ), and (3) hygromagmaphile elements.

In fresh samples from both Holes 550B and 551 (LOI $<2 \% ; \mathrm{K}_{2} \mathrm{O}<0.1 \%$ ) the concentrations of trace alkali

Table 5. Trace element data (ppm), Holes 550B and 551.

\begin{tabular}{|c|c|c|c|c|c|c|c|c|c|c|c|c|c|c|}
\hline \multirow{2}{*}{$\begin{array}{l}\text { Element } \\
\text { Sample }\end{array}$} & \multirow{2}{*}{$\begin{array}{c}\mathrm{Sc} \\
\mathrm{NAA}^{\mathrm{a}}\end{array}$} & \multirow{2}{*}{$\begin{array}{c}\mathrm{Ti} \\
\mathrm{XRF}^{\mathrm{b}}\end{array}$} & \multirow{2}{*}{$\begin{array}{c}\mathrm{V} \\
\mathrm{XRF}\end{array}$} & \multirow{2}{*}{$\begin{array}{c}\mathrm{Cr} \\
\mathrm{XRF}\end{array}$} & \multirow{2}{*}{$\begin{array}{l}\mathrm{Mn} \\
\mathrm{XRF}\end{array}$} & \multirow{2}{*}{$\begin{array}{c}\mathrm{Fe} \\
\mathrm{XRF}\end{array}$} & \multicolumn{2}{|c|}{ Co } & \multicolumn{2}{|c|}{$\mathrm{Ni}$} & \multirow{2}{*}{$\begin{array}{l}\mathrm{Zn} \\
\mathrm{XRF}\end{array}$} & \multirow{2}{*}{$\begin{array}{c}\mathrm{Rb} \\
\mathrm{XRF}\end{array}$} & \multirow{2}{*}{$\begin{array}{c}\mathrm{Sr} \\
\mathrm{XRF}\end{array}$} & \\
\hline & & & & & & & XRF & NAA & XRF & NAA & & & & \\
\hline $550 \mathrm{~B}-26-1,33-36$ & 45.6 & 8160 & 344 & 291 & 930 & 71750 & 54 & 58 & 95 & 102 & 70 & 6 & 167 & \\
\hline $550 \mathrm{~B}-26-3,88-91$ & 42.2 & 8940 & 322 & 245 & 1390 & 87570 & 48 & 51 & 102 & 109 & 76 & $<1$ & 126 & \\
\hline $550 \mathrm{~B}-27-1,65-68$ & 47.1 & 10440 & 389 & 321 & 620 & 86240 & 54 & 55 & 83 & 83 & 90 & $<1$ & 179 & \\
\hline $550 \mathrm{~B}-27-3,33-36$ & 44.4 & 9960 & 401 & 313 & 1240 & 78540 & 53 & 53 & 117 & 114 & 90 & $<1$ & 173 & \\
\hline 550B-28-1, 94-97 & 46.5 & 6960 & 468 & 336 & 1240 & 64680 & 72 & 74 & 116 & 129 & 91 & 8 & 188 & \\
\hline $550 \mathrm{~B}-28-2,72-74$ & 43.7 & 8940 & 357 & 234 & 1470 & 79870 & 46 & 49 & 81 & 82 & 86 & $<1$ & 140 & \\
\hline $550 \mathrm{~B}-28-5,129-131$ & 42.2 & 8940 & 346 & 209 & 1550 & 80290 & 47 & 49 & 83 & 87 & 79 & $<1$ & 124 & \\
\hline 550B-29-1, 1-5 & 45.7 & 9600 & 389 & 285 & 930 & 81690 & 52 & 56 & 90 & 97 & 86 & 2 & 165 & \\
\hline 550B-29-3, 5-8 & 42.6 & 8820 & 339 & 210 & 1550 & 87850 & 48 & 48 & 77 & 81 & 75 & $<1$ & 124 & \\
\hline $550 \mathrm{~B}-29-4,57-60$ & 40.9 & 8220 & 354 & 234 & 1320 & 76720 & 44 & 46 & 72 & 58 & 75 & $<1$ & 147 & \\
\hline $550 \mathrm{~B}-30-1,32-37$ & 44.0 & 8580 & 352 & 247 & 1010 & 76230 & 50 & 52 & 80 & 84 & 82 & 7 & 152 & \\
\hline $550 \mathrm{~B}-30-5,0-4$ & 38.9 & 7380 & 295 & 195 & 1320 & 74830 & 41 & 44 & 71 & 79 & 67 & $<1$ & 122 & \\
\hline $551-8-1,129-132$ & 39.3 & 6540 & 244 & 328 & 1010 & 57050 & 60 & 68 & 143 & 140 & 58 & 10 & 117 & \\
\hline $551-9-4,47-52$ & 34.9 & 5520 & 208 & 260 & 1080 & 66150 & 31 & 35 & 61 & 61 & 61 & 15 & 118 & \\
\hline $551-10-3,35-39$ & 37.5 & 6180 & 234 & 288 & 1010 & 59570 & 51 & 58 & 126 & 129 & 56 & $<1$ & 110 & \\
\hline $551-11-5,98-102$ & 43.5 & 6960 & 304 & 358 & 1080 & 54250 & 56 & 63 & 98 & 99 & 68 & $<1$ & 108 & \\
\hline $551-12-3,99-103$ & 45.0 & 8640 & 339 & 347 & 1320 & 60270 & 47 & 50 & 78 & 78 & 80 & $<1$ & 126 & \\
\hline $551-13-5,72-75$ & 42.7 & 7800 & 297 & 282 & 1160 & 74340 & 44 & 46 & 69 & 69 & 60 & $<1$ & 113 & \\
\hline $551-14-1,23-27$ & 39.9 & 10320 & 232 & 311 & 1240 & 78190 & 45 & 48 & 70 & 74 & 65 & $<1$ & 125 & \\
\hline Element & $\mathbf{y}$ & $\mathrm{Zr}$ & $\mathrm{Nb}$ & $\mathrm{Sb}$ & Cs & $\mathrm{Ba}$ & $\mathrm{La}$ & $\mathrm{Ce}$ & Eu & $\mathrm{Tb}$ & $\mathrm{Hf}$ & $\mathrm{Ta}$ & Th & U \\
\hline Sample & $\mathrm{XRF}$ & XRF & XRF & NAA & NAA & NAA & NAA & NAA & NAA & NAA & NAA & NAA & NAA & NAA \\
\hline $550 \mathrm{~B}-26-1,33-36$ & 32 & 81 & 2 & & 0.05 & & 2.90 & 8.2 & 1.24 & 0.72 & 2.12 & 0.14 & 0.13 & 0.42 \\
\hline $550 \mathrm{~B}-26-3,88-91$ & 35 & 92 & 4 & & & 23 & 3.03 & 8.0 & 1.22 & 0.76 & 2.56 & 0.23 & 0.22 & \\
\hline $550 \mathrm{~B}-27-1,65-68$ & 35 & 95 & 4 & 0.01 & & & 2.88 & 7.8 & 1.35 & 0.77 & 2.71 & 0.25 & 0.26 & \\
\hline $550 \mathrm{~B}-27-3,33-36$ & 36 & 100 & 5 & 0.01 & & 11 & 3.20 & 10.5 & 1.26 & 0.77 & 2.59 & 0.24 & 0.22 & \\
\hline 550B-28-1, 94-97 & 36 & 100 & 4 & 0.05 & 0.06 & & 4.00 & 9.7 & 1.33 & 0.81 & 2.67 & 0.25 & 0.25 & 0.53 \\
\hline $550 \mathrm{~B}-28-2,72-74$ & 36 & 89 & 3 & & & & 2.86 & 9.9 & 1.23 & 0.77 & 2.51 & 0.20 & 0.18 & \\
\hline $550 \mathrm{~B}-28-5,129-131$ & 35 & 95 & 4 & & & & 2.84 & 9.7 & 1.23 & 0.74 & 2.38 & 0.20 & 0.19 & \\
\hline 550B-29-1, 1-5 & 33 & 97 & 4 & & 0.03 & & 3.06 & 8.4 & 1.21 & 0.74 & 2.40 & 0.22 & 0.21 & 0.08 \\
\hline $550 \mathrm{~B}-29-3,5-8$ & 35 & 91 & 3 & 0.01 & 0.02 & 9 & 2.90 & 6.6 & 1.20 & 0.75 & 2.33 & 0.21 & 0.20 & 0.06 \\
\hline $550 \mathrm{~B}-29-4,57-60$ & $3 \mathrm{I}$ & 91 & 4 & 0.01 & & & 2.33 & 10.4 & 1.16 & 0.66 & 2.13 & 0.19 & 0.17 & 0.10 \\
\hline $550 \mathrm{~B}-30-1,32-37$ & 34 & 89 & 3 & 0.03 & 0.09 & & 3.10 & 8.3 & 1.20 & 0.72 & 2.30 & 0.18 & 0.17 & 0.33 \\
\hline 550B-30-5, 0-41 & 30 & 76 & 3 & & & & 1.45 & 5.9 & 1.07 & 0.60 & 1.91 & 0.17 & 0.16 & \\
\hline $551-8-1,129-132$ & 26 & 66 & 2 & & 0.19 & 17 & 1.26 & 5.0 & 1.03 & 0.56 & 1.64 & 0.09 & 0.10 & \\
\hline $551-9-4,47-52$ & 23 & 55 & 2 & 0.03 & 0.55 & 19 & 1.46 & 5.4 & 0.90 & 0.49 & 1.46 & 0.09 & 0.08 & 0.06 \\
\hline $551-10-3,35-39$ & 25 & 58 & 1 & & 0.02 & & 1.38 & 5.2 & 0.98 & 0.53 & 1.48 & 0.08 & 0.08 & 0.08 \\
\hline $551-11-5,98-102$ & 25 & 65 & 2 & 0.01 & & & 1.67 & 6.9 & 0.98 & 0.56 & 1.68 & 0.11 & 0.11 & \\
\hline $551-12-3,99-103$ & 31 & 78 & 3 & & 0.01 & & 2.60 & 8.5 & 1.18 & 0.72 & 2.18 & 0.16 & 0.18 & \\
\hline $551-13-5,72-75$ & 31 & 82 & 2 & & & & 2.30 & 4.8 & 1.15 & 0.62 & 2.14 & 0.15 & 0.17 & 0.06 \\
\hline $551-14-1,23-27$ & 29 & 74 & 2 & & & & 1.80 & 12.4 & 1.14 & 0.62 & 1.94 & 0.13 & 0.15 & \\
\hline
\end{tabular}

a $\mathrm{NAA}=$ neutron activation analyses. 
elements are very low $(\mathrm{Rb}<1 \mathrm{ppm} ; \mathrm{Cs}<0.02 \mathrm{ppm})$ and are typical of oceanic tholeiites. The hypothesis of a continental tholeiitic origin (flood basalts) for Hole 551 basalts can thus be excluded, because continental tholeiites are consistently enriched in $\mathrm{Rb}, \mathrm{Cs}$, and $\mathrm{Ba}$, in contrast with ocean-floor basalts (Bertrand et al., 1982; Erlank and Hofmeyer, 1968). In altered samples from Leg 80 , there is a strong correlation linked to the degree of alteration between the amounts of $\mathrm{Rb}$ (up to $15 \mathrm{ppm}$ ) and Cs (up to $0.55 \mathrm{ppm}$ ) and the values of $\mathrm{K}_{2} \mathrm{O}$ and LOI. This kind of chemical variation reflects progressive alteration of basalts by low-temperature seawater, a good example of which comes from Holes $417 \mathrm{~A}$ and 418 drilled during Legs 51 and 52 (Donnelly et al., 1979).

Significant variations are observed for the two highpartition coefficient elements, $\mathrm{Cr}(210-358 \mathrm{ppm})$ and $\mathrm{Ni}$ (60-143 ppm). The basalts from Leg 80 sites cannot be considered as primary melts. The concentrations of $\mathrm{Cr}$ and $\mathrm{Ni}$ in these would be close to 600 and $250 \mathrm{ppm}$, respectively. Thus, they appear to be derived liquids resulting from fractional crystallization. There is no correlation between $\mathrm{Cr}$ and $\mathrm{Ni}$ amounts and the sequence of low-temperature alteration; thus, the variations of $\mathrm{Cr}$ and $\mathrm{Ni}$ in Leg 80 basalts can be considered to be of primary origin and can be ascribed to fractionation of magnesiochromite and olivine, respectively.

Concerning hygromagmaphile elements, it is noteworthy that the elements of the second and third Transition Series of Groups 3, 4, and $5(\mathrm{Y} / \mathrm{Tb}, \mathrm{Zr} / \mathrm{HF}$, and $\mathrm{Nb} / \mathrm{Ta}$ ) do not fractionate one from the other. Their ratios are close to the chondritic ratios $(\mathrm{Y} / \mathrm{Tb} \simeq 50, \mathrm{Zr} /$ $\mathrm{HF} \simeq 40$, and $\mathrm{Nb} / \mathrm{Ta} \simeq 16$ ) and are thus characteristic of oceanic tholeiites (Bougault, 1980) for both Hole $550 \mathrm{~B}$ and 551 samples. The range of variation of hygromagmaphile elements is shown in Figures 3 and 4 , in which these elements are plotted on an extended Coryell-Masuda diagram (Bougault, 1980). These patterns with low Th, Ta, and La values normalized to chondrite composition are typical of "depleted" oceanic tholeiites. This is again a reason to exclude a continental tholeiitic parentage for Hole 551 basalts, because continental tholeiites are characteristically enriched in light rare earth elements (LREE). In addition, the $\mathrm{La} / \mathrm{Ta}$ ratios of Leg 80 samples are somewhat variable; their mean values (14 for Hole 550B samples, 15 for Hole 551) are intermediate between those found for different types of Atlantic floor basalts (Bougault et al., 1979).

\section{${ }^{40} \mathrm{~K} /{ }^{40} \mathrm{Ar}$ RADIOMETRIC DATING}

Five samples (two recovered from Hole 550B and three from Hole 551) were dated using the conventional ${ }^{40} \mathrm{~K} /{ }^{40} \mathrm{Ar}$ method. A previous study of the chemical and mineralogical characters of the samples was done to determine their degree and type of alteration-for example, the nature of secondary veinlets in the basalt groundmass, the nature of the filling of vesicles, the presence of chlorite, a local increase of potassium around the feldspars, weathering of clinopyroxenes and oxides, and weathering and abundance of glass in the basalts.

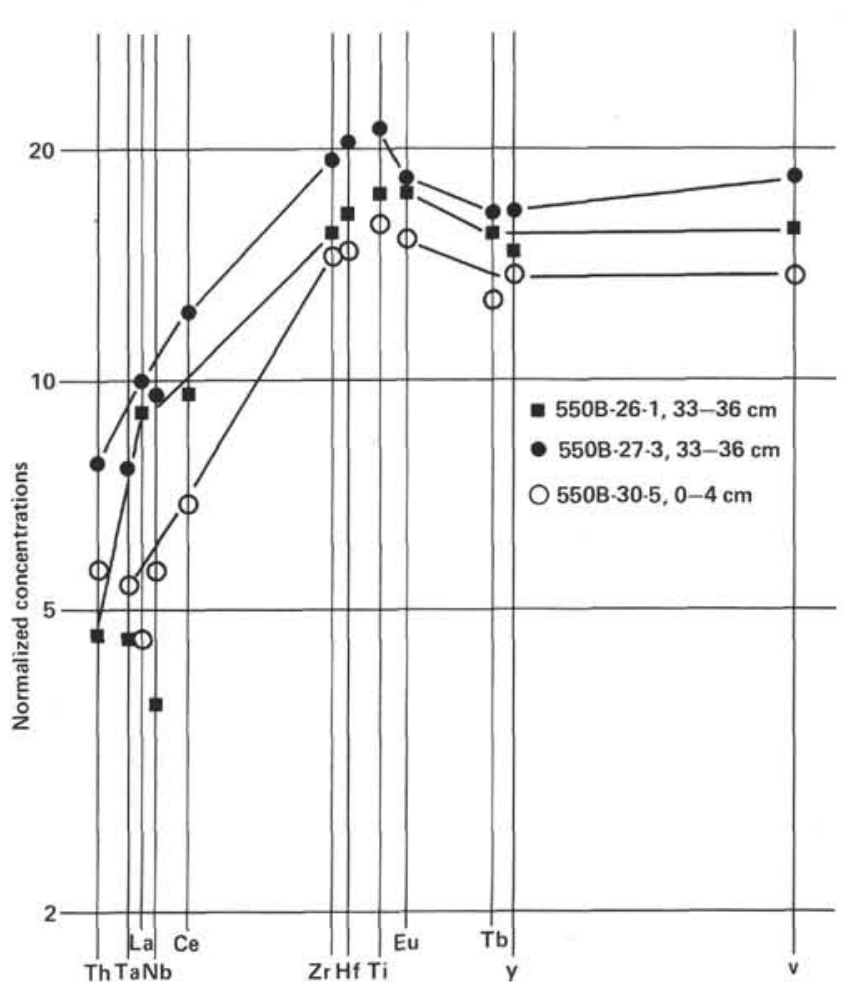

Figure 3. Extended Coryell-Masuda plots for selected samples from Hole 550B. The concentrations of samples normalized to chondrite concentrations are plotted versus the elements arranged by their decreasing affinity for the liquid phase of the magma.

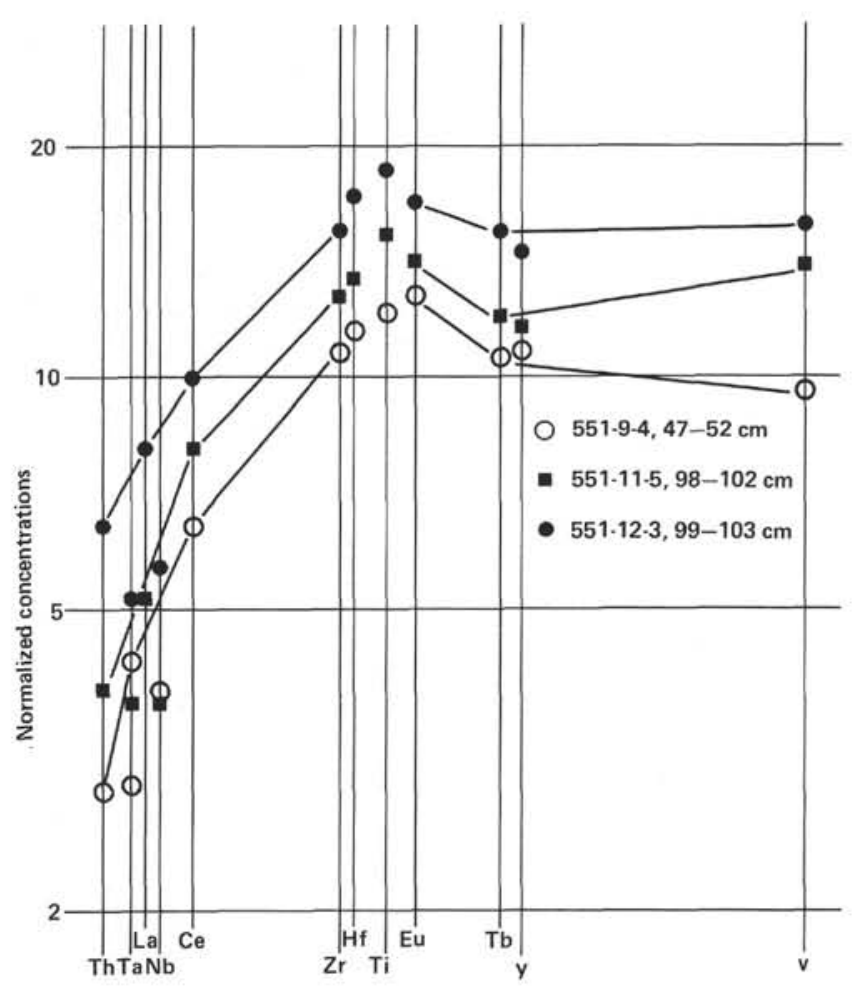

Figure 4. Extended Coryell-Masuda plots for selected samples from Hole 551 . 


\section{EXPERIMENTAL PROCEDURE}

Argon was extracted from whole rock ( $1 \mathrm{~g}$ in each case) reduced to grains of 0.3 to $0.1 \mathrm{~mm}$ and cleaned with distillated water to eliminate the crushing powder adhering to the grains. When vesicles were too numerous in the basalt, grains for analyses ( $\mathrm{Ar}$ and $\mathrm{K}$ ) were handpicked (Sample 551-8-1, 128-132 cm).

Isotopic analysis was done using isotope dilution technique where an ${ }^{38} \mathrm{Ar}$ spike is buried as positive ions in an aluminium foil target, as described in Bellon et al. (1981), by $180^{\circ}$ mass spectrometry running in static mode. The ion accelerating voltage was between 500 and 600 $\mathrm{V}$, and the permanent magnetic field was $3300 \mathrm{G}$. The electron accelerating voltage in the ion source was set at $50 \mathrm{~V}$. After each analysis, mass discrimination correction was applied using air Ar analysis introduced in the mass spectrometer at a level equivalent to that of each analyzed sample. The correction was always $<1 \%$ per mass atomic unit.

Potassium was analyzed both by X-ray fluorescence (C.O.B. laboratories) and atomic absorption spectrometry (Varian AA6) (Université de Bretagne Occidentale laboratories). A good agreement has been found among the results obtained by the two techniques. Atomic absorption determinations were used in age calculations because this technique was run on the rock fraction from which the $\mathrm{Ar}$ was extracted.

Age calculations were achieved using the following formula: age $t$ $(\mathrm{m} . \mathrm{y})=.4153.9 \log _{10}\left(1+142.33{ }^{40} \mathrm{Ar}^{*} / \mathrm{K}\right)$, in which the constants are those of Steiger and Jäger (1977). ${ }^{40} \mathrm{Ar}^{*}$ is expressed in cubic centimeters per gram and $\mathrm{K}$ in grams. Results are given in Table 6.

\section{Results and Discussion}

From Hole 550B, two samples give ages of $69.6 \pm$ $3.5 \mathrm{~m} . \mathrm{y}$. and $76.4 \pm 3.6 \mathrm{~m}$.y. The oldest age is given by the basalt most depleted in $\mathrm{K}_{2} \mathrm{O}(0.065 \%$ versus $0.09 \%)$.

These ages do not agree with the fossil age, since these rocks have been recovered in the $33 \mathrm{~m}$ of volcanic rocks and minor limestones cored below the uppermost Albian calcareous mudstones of about 95 m.y. in age (Odin and Kennedy, 1982). In addition, three of the six lava flows cored in the hole are covered by microfossilbearing limestones, the age of which is probably not very different from the age of the overlying sediments. The two radiometric ages are too young in comparison with the age of the sediments.

From Hole 551, three samples give ages of $42.7 \pm$ 2.15 m.y., $48.9 \pm 2.45$ m.y., and $62.5 \pm 3.15$ m.y., respectively. Here also the oldest age is given by the $\mathrm{K}_{2} \mathrm{O}$ poorest basalt $(0.114 \%)$. In contrast there is no strong age discrepancy between a rich $\mathrm{K}_{2} \mathrm{O}$ basalt $(0.827 \%)$ and a poor $\mathrm{K}_{2} \mathrm{O}$ basalt $(0.145 \%)$. The difference between the two groups of ages seems to be linked to the type of volcanic rocks; the oldest age is from a massive basalt, and the youngest is from a pillow basalt. In this case again the ages do not agree with the fossil age because the recovered $59 \mathrm{~m}$ of basalt are below upper Cenomanian chalks. According to Odin and Kennedy (1982), the age of volcanism should be older than 91 m.y.

The radiometric ages are highly distorted and inconsistent with the apparent age of the oceanic crust as con- cluded from sedimentary rocks. A more detailed investigation of each dated system is needed to propose one or more mechanisms which would lead to reducing the radiometric ages.

From mineralogical and geochemical studies, we must remember the strong influence of the progressive alteration of basalts by low temperature seawater. The radiometric data support and reflect this phenomenon, but it seems that the K-enrichment varies among the different dated samples.

1. The higher radiometric ages were obtained from massive lavas (Samples 550B-26-3, 88-91 cm; 550B-27-1, $65-68 \mathrm{~cm}$; and $551-13-5,72-75 \mathrm{~cm}$ ).

2. The highest $\mathrm{K}$ content was found is a deep, fractured pillow lava where extensive circulation was probably favored by the fractures.

3. The progressive alteration was probably influenced by the relative position of the lavas with respect to their depth BSF: the youngest radiometric ages are those of pillow lavas and massive lavas from Hole 551 at a depth of $150 \mathrm{~m}$ BSF.

4. The oldest ages are those of massive lavas from Hole 550B at a depth of $690 \mathrm{~m}$ BSF.

5 . In this way a correlation appears between radiometric ages and $\mathrm{K}_{2} \mathrm{O}$ content for four samples (Fig. 5). The line joining the different points crosses the $y$ axis (time) between 90 and 100 m.y., the possible age of ba-

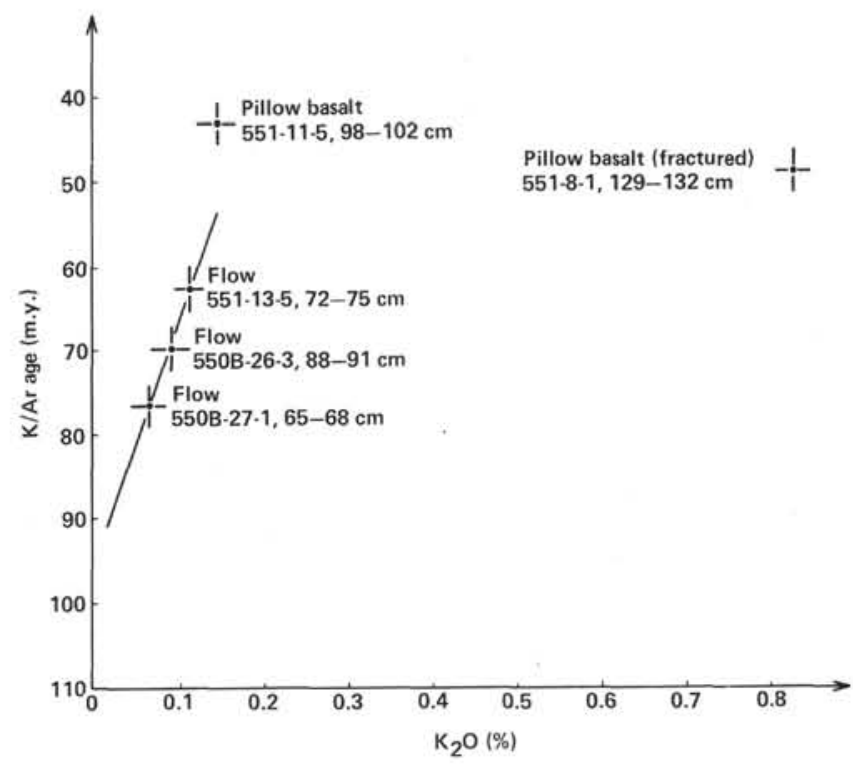

Figure 5. Plot of $\mathrm{K} / \mathrm{Ar}$ ages versus $\mathrm{K}_{2} \mathrm{O}$ content of basalts from Leg 80.

Table $6 .{ }^{40} \mathrm{~K} /{ }^{40} \mathrm{Ar}$ radiometric analyses.

\begin{tabular}{ccccccc}
\hline Sample & $\begin{array}{c}\text { Age (m.y.) } \\
( \pm \text { uncertainty) }\end{array}$ & $\begin{array}{c}{ }^{40} \mathrm{Ar} * \\
\left(\times 10^{-7} \mathrm{cc} / \mathrm{g}\right)\end{array}$ & $\begin{array}{c}\mathrm{K}_{2} \mathrm{O} \\
(\%)\end{array}$ & $\begin{array}{c}\text { Weight } \\
(\mathrm{g})\end{array}$ & $\begin{array}{c}{ }^{40} \mathrm{Ar}_{\mathrm{ArT}}^{\bullet} \\
(\%)\end{array}$ & $\begin{array}{c}\text { Exp. } \\
\text { number }\end{array}$ \\
\hline $551-8-1,129-132 \mathrm{~cm}$ & $48.9 \pm 2.5$ & 13.32 & 0.827 & 1.0264 & 69.9 & $\mathrm{~B}-88$ \\
$11-5,98-102 \mathrm{~cm}$ & $42.7 \pm 2.1$ & 2.036 & 0.145 & 1.0061 & 25 & $\mathrm{~B}-83$ \\
$13-5,72-75 \mathrm{~cm}$ & $62.5 \pm 3.1$ & 2.352 & 0.114 & 1.0110 & 28 & $\mathrm{~B}-87$ \\
$550 \mathrm{~B}-26-3,88-91 \mathrm{~cm}$ & $69.6 \pm 3.5$ & 2.074 & 0.09 & 1.0039 & 19.7 & $\mathrm{~B}-82$ \\
$27-1,65-68 \mathrm{~cm}$ & $76.4 \pm 3.8$ & 1.646 & 0.065 & 1.0120 & 31 & B-125 \\
\hline
\end{tabular}


salt emplacement. This point corresponds to an initial $\mathrm{K}_{2} \mathrm{O}$ content close to $0 \%$ in the basalts.

\section{CONCLUSIONS}

The basalt samples from Leg 80 sites are typical LREE-depleted oceanic tholeiites with well-conserved primary mineralogy and geochemistry; they do not depart from the compositions of Atlantic ocean-floor basalts. The basalts have suffered various degrees of lowtemperature seawater alteration resulting in the development of secondary parageneses of the "brownstone facies" (brown clays and adularia) and enrichment in K, $\mathrm{Rb}$, and $\mathrm{Cs}$.

The mineralogical and geochemical compositions of basalts from Holes 550B and 551 are almost identical; there is no petrological argument for postulating different magmatic parentages or geodynamic conditions of emplacement for the basalts from the two sites. In particular, Hole 551 basalts are clearly different (low alkali contents, LREE-depleted) from the continental tholeiites or flood basalts emplaced on the margins of oceanizing domains mainly during the prerift magmatic, or possibly the synrift, stages.

$\mathrm{K} / \mathrm{Ar}$ dating failed to give valuable emplacement ages for Leg 80 basalts because $\mathrm{K}$ was mobile during latestage low-temperature alteration.

\section{REFERENCES}

Bellon, H., Quoc Buù, N., Chaumont J., and Philippet, J. C., 1981. Implantation ionique d'argon dans une cible support. Application au traçage isotopique de l'argon contenu dans les minéraux et les roches. C. R. Hebd. Seances Acad. Sci. Ser. C, 292:977-980.

Bertrand, H., Dostal, J., and Dupuy, C., 1982. Geochemistry of Early Mesozoic tholeiites from Morocco. Earth Planet. Sci. Lett., 58: 225-239.

Bougault, H., 1980. Contribution des éléments de transition à la compréhension de la genèse des basaltes océaniques. Analyse des éléments traces dans les roches par spectrométrie de fluorescence X. [Thesis]. Université de Paris VI, Paris.

Bougault, H., Cambon, P., and Toalhouat, H., 1977. X-ray spectrometric analysis of trace elements in rocks. Correction for instrumental interferences. X-Ray Spectrom., 6(2):66-72.

Bougault, H., Joron, J. L., and Treuil, M., 1979. Alteration, fractional crystallization, partial melting, mantle properties from trace ele- ment in basalts recovered in the North Atlantic. In Talwani, M., Harrison, C. G., and Hayle, D. E. (Eds.), Deep Drilling Results in the Atlantic Ocean: Ocean crust: Maurice Ewing Series (Vol. 2): American Geophysical Union, pp. 352-368.

Cann, J. R., 1979. Metamorphism in the Ocean Crust. In Talwani, M., Harrison, C. G., and Hayle, D. E. (Eds.), Deep Drilling Results in the Atlantic Ocean: Ocean crust: Maurice Ewing Series (Vol. 2): American Geophysical Union, pp. 230-238.

Donnelly, T. W., Thompson, G., and Robinson, P. T., 1979. Very lowtemperature hydrothermal alteration of the oceanic crust and the problem of fluxes of potassium and magnesium. In Talwani, M., Harrison, C. G., and Hayle, D. E. (Eds.), Deep Drilling Results in the Atlantic Ocean: Ocean crust: Maurice Ewing Series (Vol. 2): American Geophysical Union, pp. 383-390.

Erlank, A. J., and Hofmeyer, R., 1968. K-Rb ratios in Mesozoic tholeiites from Antarctica, Brazil and India. Earth Planet. Sci. Lett., 4:33-38.

Leterrier, J., Maury, R. C., Thonon, P., Girard, D., and Marchal, M., 1982. Clinopyroxene compositions as a method of identification of the magmatic affinities of palaeo-volcanic series. Earth Planet. Sci. Lett., 59:139-154.

Maurel, C., and Maurel, P., 1982. Étude expérimentale de la distribution de l'aluminium entre bain silicaté basique et spinelle chromifère. Implications pétrogénétiques: teneur en chrome des spinelles. Bull. Mineral., 105:197-202.

Natland, J. H., 1978. Crystal morphologies in basalts from DSDP Site $395.23^{\circ} \mathrm{N}, 46^{\circ} \mathrm{W}$, Mid-Atlantic Ridge. In Melson, W. G., Rabinowitz, P. D., et al., Init. Repts. DSDP, 45: Washington (U.S. Govt. Printing Office), 423-446.

Odin, G. S., and Kennedy, W. J., 1982. Mise à jour de l'échelle des temps mésozoïques. C.R. Hebd. Seances Acad. Sci. Ser. D, 294: 383-386.

Sigurdsson, H., and Schilling, S. G., 1976. Spinels in Mid-Atlantic Ridge basalts: chemistry and occurrence. Earth Planet. Sci. Lett., 29:7-20.

Smith, D., and Lindsley, D. H., 1971. Stable and metastable augite crystallization trends in a single basalt flow. Am. Mineral., 56: 225-233.

Steiger, R. H., and Jäger, E., 1977. Sub-commission on geochronology: convention on the use of decay constants in geo and cosmo chronology. Earth Planet. Sci. Lett., 26:359-362.

Treuil, M., Jaffrezic, H., Deschamps, N., Derre, C., Guichard, F., Joron, J. L., Pelletier, B., Novotry, S., and Courtois, C., 1973. Analyse des lanthanides du Hafnium, du scandium, du chrome, du manganèse, du cobalt, du cuivre et du zinc dans les minéraux et les roches par activation neutronique. J. Radioanal. Chem., 18: 55-68.

Date of Initial Receipt: January 14, 1983

Date of Acceptance: July 18, 1983 